\title{
Glyceroglycolipids from Euphorbia nicaeensis All. with antiinflamatory activity
}

\author{
Francesca Cateni* $^{\mathrm{a}}$, Gioacchino Falsone ${ }^{\mathrm{a}}$, Jelena Zilic ${ }^{\mathrm{a}}$, Paolo Bonivento ${ }^{\mathrm{a}}$, Marina \\ Zacchigna $^{a}$, Dušan Žigon ${ }^{b}$, Silvio Sosa ${ }^{c}$, and Gianmario Altinier ${ }^{c}$ \\ ${ }^{a}$ Department of Pharmaceutical Sciences, University of Trieste, P.zle Europa 1, 34127 Trieste, \\ Italy \\ ${ }^{b}$ Department of Environmental Sciences, “Jožef Stefan” Institute, Jamova 39, 1000 Ljubljana, \\ Slovenia \\ ${ }^{c}$ DEMREP, University of Trieste, Via A. Valerio 6, 34127 Trieste \\ E-mail: cateni@univ.trieste
}

In honour of Professor Vincenzo Tortorella in the occasion of his " Fuori Ruolo " status (received 06 Nov 03; accepted 15 Jan 04; published on the web 21 Jan 04)

\begin{abstract}
Two new glyceroglycolipids as well as three known ones were isolated from the glyceroglycolipids molecular species obtained from two less polar fractions of the $\mathrm{MeOH}$ extract of the plant Euphorbia nicaeensis All. using normal and reversed phase column flash chromatography. The structures of the isolated glyceroglycolipids were determined on the basis of chemical and spectroscopic evidences.

Two new glyceroglycolipids were isolated for the first time from Euphorbiaceae, 2 was assigned as (2S)-2,3-O-di-(hexadecanoyl)-glyceryl- $\beta$-D-galactopyranoside and 5 as (2S)-3-O-(9, 12octadecadienoyl)-glyceryl- $\beta$-D-galactopyranoside. The isolated glyceroglycolipids exhibited an interesting anti-inflammatory activity.
\end{abstract}

Keywords: Euphorbia nicaeensis All, plant, glyceroglycolipids, anti-inflammatory activity

\section{Introduction}

Euphorbiaceae plants are well known to contain irritant and tumor-promoting constituents. ${ }^{1}$ In particular, diterpenoids from the Euphorbiaceae have been found to possess interesting biological activities. $^{2}$ Euphorbia nicaeensis All. is a hardy perennial which inhabits sandy coasts and shingle beaches and is native to the entire Mediterranean region.

Chemical constituents of this species have been investigated previously and the presence of tetracyclic triterpenoids as well as sphingolipids has been reported. ${ }^{3,4}$ Extracts of the roots of 
Euphorbia nicaeensis All. have showed significant cytotoxic activity, whereas extracts of the aerial parts showed only moderate activity. ${ }^{3}$ Besides, phytochemical studies have been reported previously dealing with epicuticular wax constituents. ${ }^{5}$ Previous pharmacological studies of extracts from this plant showed an anti-inflammatory action and this finding prompted us to investigate the chemical constituents of Euphorbia nicaeensis All.. In this paper, we report the isolation and structure elucidation of five glyceroglycolipids 1-5 (Figure 1), obtained from two less polar fractions of the $\mathrm{MeOH}$ extract of the aerial parts of E. nicaeensis All. which were separated by normal and reversed phase flash chromatography (Scheme 1). Although various galactosyl diglycerides and monoglycerides have been isolated and characterized, differing in the acyl chains in comparison to the glyceroglycolipids isolated from Euphorbiaceae, the biological functions of these compounds have not been fully elucidated. ${ }^{6}$

The glyceroglycolipids $\mathbf{2}$ and $\mathbf{5}$ have been isolated for the first time from Euphorbiaceae, while the chemical structures of the compounds $\mathbf{1}, \mathbf{3}$ and $\mathbf{4}$ were proposed in our preliminary papers. ${ }^{7-9}$

Galactolipids are major constituents of the chloroplast membrane in plant kingdom. The biological functions as well as occurrence and distribution of galactolipids is an area of intense interest and investigation. ${ }^{10}$ It was recently shown that glyceroglycolipids analogues have a promising inhibitory effect on Epstein-Barr virus early antigen (EBV-EA) activation induced by the tumour promoter 12-O-tetradecanoylphorbol-13-acetate (TPA). ${ }^{11,12}$

The anti-inflammatory activity of the isolated compounds evaluated as inhibition of the Croton oil-induced ear oedema in mice is also described.

\section{Results and Discussion}

The ${ }^{1} \mathrm{H}$ NMR and ${ }^{13} \mathrm{C}$ NMR spectra of $\mathbf{2}$ closely resembled those of $\mathbf{1}$ except for the signals due to the fatty acid moieties. Treatment of 2 with $\mathrm{NaOH}-\mathrm{MeOH}$ and with $\mathrm{BF}_{3} / \mathrm{MeOH}$ as carried out for the hydrolysis of $\mathbf{1}$ furnished the glyceryl- $\beta$-D-galactopyranoside (6) together with a mixture of fatty acid methyl esters. The fatty acid composition in $\mathbf{2}$ was determined by gas-liquid chromatographic (GLC) analysis and these liberated methyl esters indicated the presence only of a $\mathrm{C}_{16}$ fatty acid. Furthermore, the ${ }^{1} \mathrm{H}-\mathrm{NMR}$ and ${ }^{13} \mathrm{C}-\mathrm{NMR}$ analyses of $\mathbf{2}$ in comparison with $\mathbf{1}$ indicated that the fatty acid residues in 2 are attached to 2-OH and 3-OH of the glycerol moiety. As a result, the chemical structure of 2 has been determined as (2S)-2,3-O-di-(hexadecanoyl)glyceryl- $\beta$-D-galactopyranoside (2).

The FT-IR spectrum of 3 shows the presence of hydroxyl and ester $\left(1740 \mathrm{~cm}^{-1}\right)$ groups, while the ${ }^{1} \mathrm{H}$ NMR and ${ }^{13} \mathrm{C}$ NMR spectra of $\mathbf{3}$ showed signals which were characteristically attributable to a digalactosyl diacylglycerol: a deformed triplet at $\delta=0.95 \mathrm{ppm}$ and a broadened signal at $\delta=$ $1.20 \mathrm{ppm}$, both due to fatty acid residues, a mass of signals at $\delta=4.34-4.64 \mathrm{ppm}$ (sugar moiety) and doublets at $\delta=5.45 \mathrm{ppm}\left(\mathrm{H}-1^{\prime \prime}\right)$ and $4.75 \mathrm{ppm}\left(\mathrm{H}-1^{\prime}\right)$ attributed to $\alpha$ and $\beta$ anomeric protons, respectively. 

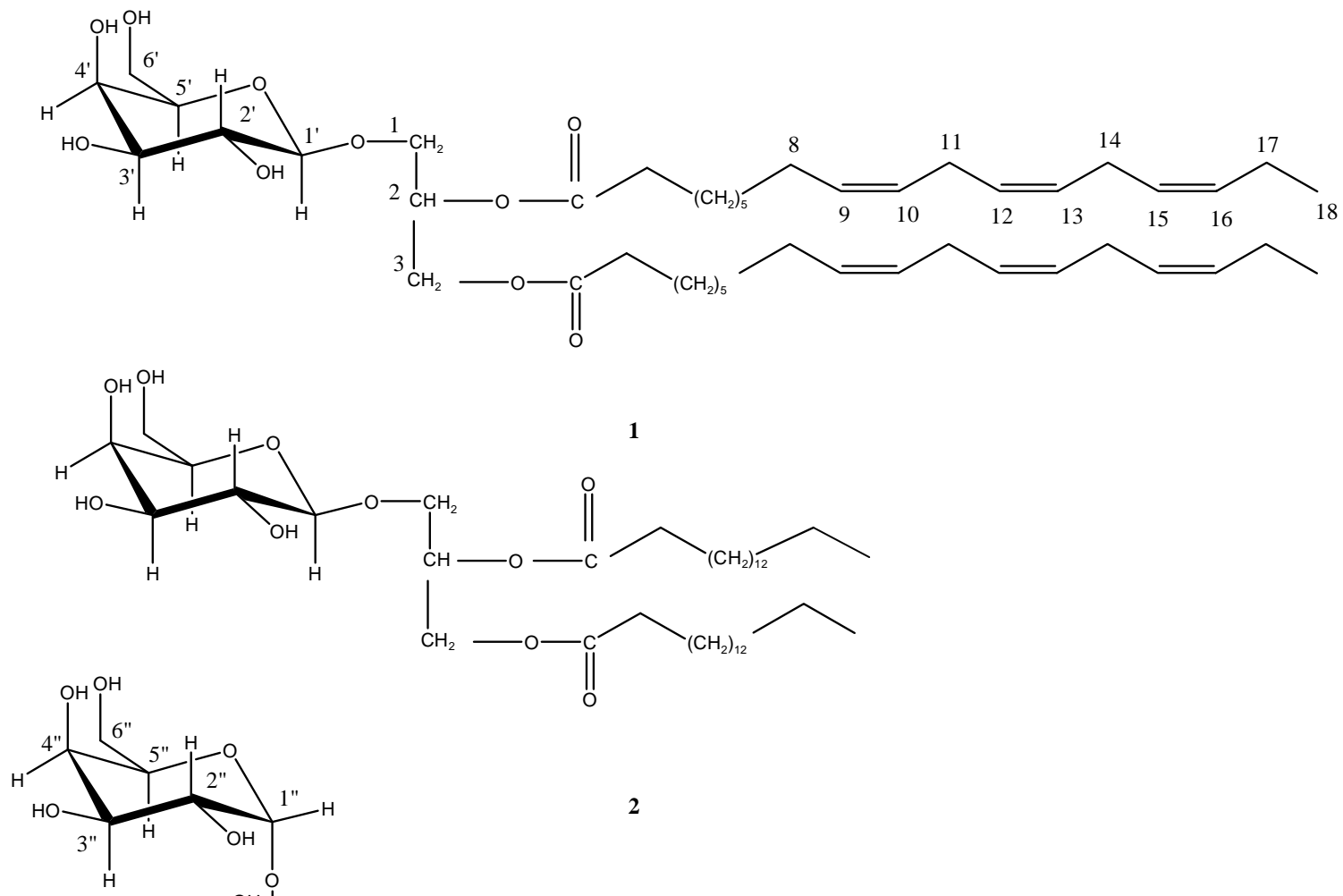

2
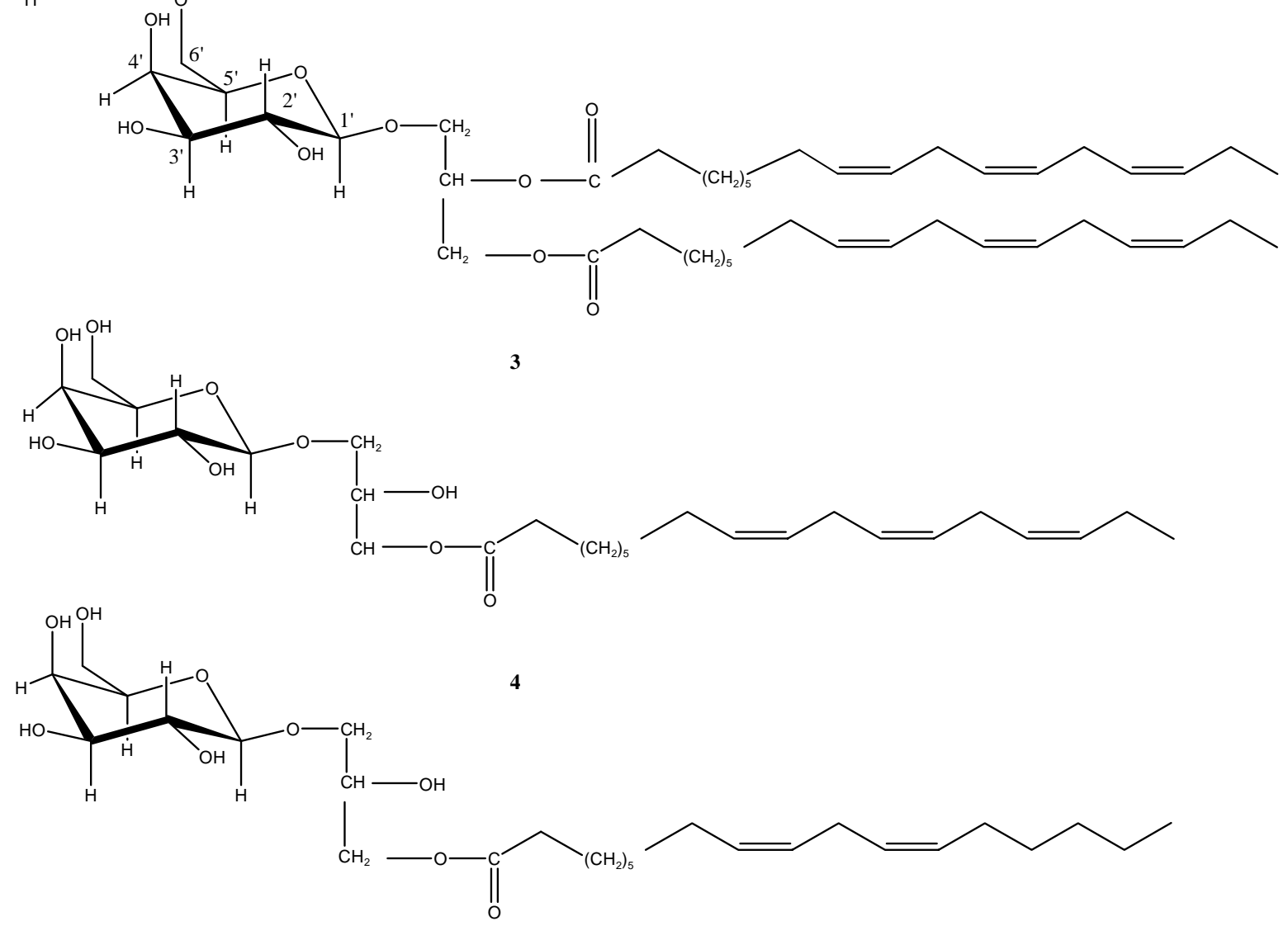

5

Figure 1. Chemical structures of glyceroglycolipids 1-5. 
Methanol extract of plant Euphorbia nicaeensis All.

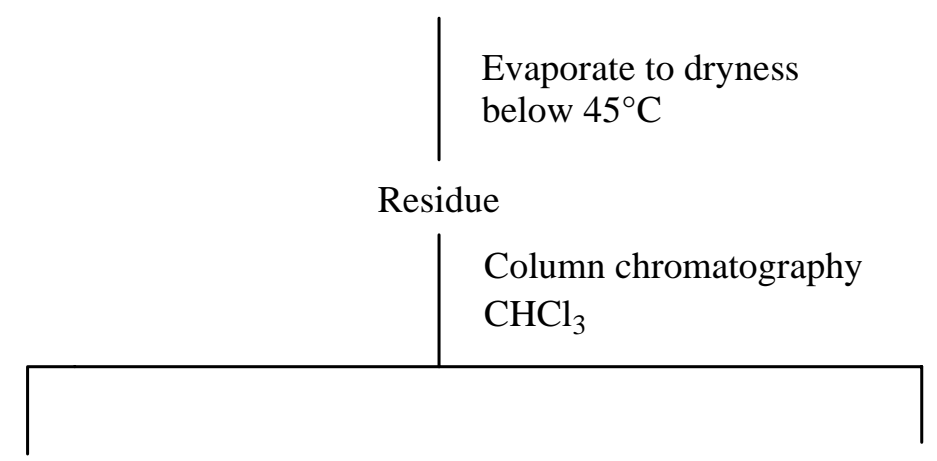

Fraction A

(Lipids, diterpenoids)

Fraction B

Column Chromatography $\mathrm{MeOH}$

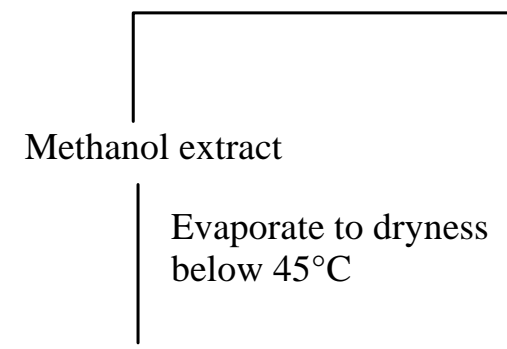

Residue from methanol extract

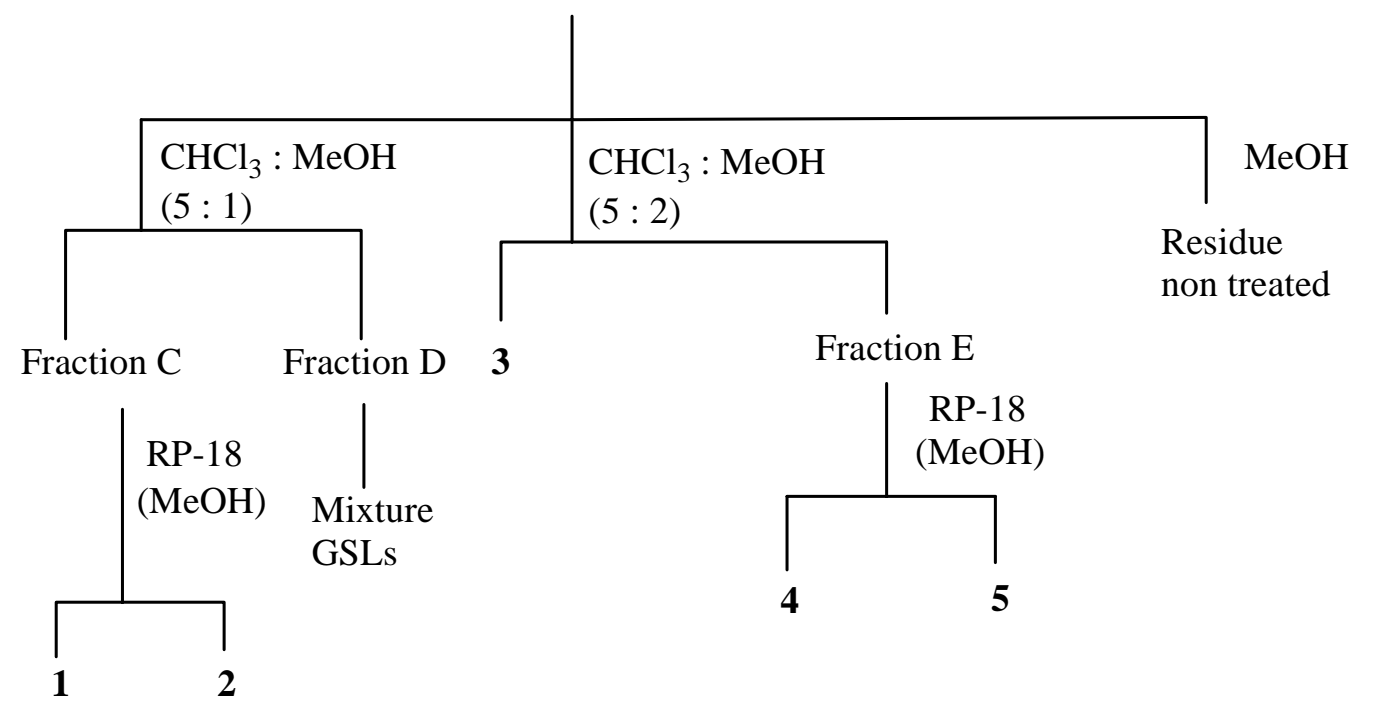

Scheme 1. Isolation procedure of glyceroglycolipids 1-5.

The ${ }^{1} \mathrm{H}-\mathrm{NMR},{ }^{13} \mathrm{C}-\mathrm{NMR}$ and ${ }^{1} \mathrm{H}-{ }^{1} \mathrm{H}$ COSY correlations data of the compound $\mathbf{3}$ are reported in Table 2. In the FAB-MS spectrum of 3 the molecular ion at $\mathrm{m} / \mathrm{z}=959(\mathrm{M}+\mathrm{Na})^{+}$and the characteristic fragments at $\mathrm{m} / \mathrm{z}=595(\mathrm{M}+\mathrm{Na}-364)^{+}$and $335\left(\mathrm{C}_{18} \mathrm{H}_{29} \mathrm{O}+74\right)^{+}$have been observed. In the negative ion FAB-MS spectrum the molecular ion of the compound 3 at $\mathrm{m} / \mathrm{z}=$ $935(\mathrm{M}-\mathrm{H})^{-}$and the presence of the fatty acid at $\mathrm{m} / \mathrm{z}=277\left(\mathrm{C}_{18} \mathrm{H}_{29} \mathrm{O}_{2}\right)^{-}$have been observed. 
Treatment of 3 with $\mathrm{NaOH}-\mathrm{MeOH}$ and with $\mathrm{BF}_{3} / \mathrm{CH}_{3} \mathrm{OH}$ furnished a glycerol digalactoside (7) and a mixture of fatty acid methyl esters. The glycerol digalactoside thus obtained was shown to be identical with (2R)-1-O-glyceryl 6'-O-( $\alpha$-D-galactopyranosyl)- $\beta$-D-galactopyranoside, which was obtained by $\mathrm{NaOH}-\mathrm{MeOH}$ and $\mathrm{BF}_{3} / \mathrm{CH}_{3} \mathrm{OH}$ treatment of a digalactosyl diacylglycerol previously isolated by us from Euphorbia peplis L., on the basis of ${ }^{13} \mathrm{C}-\mathrm{NMR}$ and $[\alpha]_{\mathrm{D}}$ comparisons. ${ }^{8}$ On the other hand, the GC analysis of the mixture of fatty acid methyl esters obtained above indicates the presence of a kind of ester, methyl linolenate so that $\mathbf{3}$ is a di-fatty acid ester of linolenic acid $\left(\mathrm{C}_{18: 3 \omega 3}\right)$. Detailed comparisons of the ${ }^{1} \mathrm{H}-\mathrm{NMR}$ and ${ }^{13} \mathrm{C}-\mathrm{NMR}$ data for 3 and 7 have shown that the fatty acid residues are attached to C-2 and C-3, respectively, in the glycerol moiety of $\mathbf{3}$. Based on the above mentioned evidences, the chemical structure of $\mathbf{3}$ has been determined as (2S)-2,3-O-di-(9, 12, 15- octadecatrienoyl)-glyceryl 6-O-( $\alpha$-D-galacto. pyranosyl)- $\beta$-D-galactopyranoside (3).

Compounds 4 and 5 showed hydroxyl groups and one ester absorption band in the FT-IR spectrum. The ${ }^{1} \mathrm{H}-\mathrm{NMR}$ spectra of $\mathbf{4}$ and $\mathbf{5}$ exhibited features of monogalactosylmonoacylglycerols (MGMGs): they showed the presence of a terminal methyl ( $\delta$ $=0.90 \mathrm{ppm}$ ), the absence of the multiplet at about $\delta=5.60 \mathrm{ppm}$ and the signal at $\delta=70.25 \mathrm{ppm}$ in the ${ }^{13} \mathrm{C}$-NMR spectra suggest that the hydroxyl group in C-2 position of the glycerol moiety is free. Detailed analysis of the homonuclear decoupling spectra defined $\beta$-D-galactopyranoside. The doublets at $\delta=4.85$ (4) and 4.90 (5) ppm in the ${ }^{1} \mathrm{H}$-NMR spectra and the signals at $\delta=$ 105.89 (4), 105.9 ppm (5) in the ${ }^{13} \mathrm{C}$-NMR spectra confirmed the $\beta$ - glycosidic bond of the sugar moiety in C-1 position of glycerol. In addition, observation of carbon signals due to one ester carbonyl at about $\delta=173.78$ (4), 173.57 (5) ppm and one terminal methyl group at 14.5 (4) and $14.25 \mathrm{ppm}(5)$ in the ${ }^{13} \mathrm{C}$-NMR spectra indicated the presence of one acyl group in $\mathbf{4}$ and 5 . The ${ }^{1} \mathrm{H}-\mathrm{NMR},{ }^{13} \mathrm{C}-\mathrm{NMR}$ and ${ }^{1} \mathrm{H}-{ }^{1} \mathrm{H}$ COSY correlations data of $\mathbf{4}$ and 5 are reported in Table 3 . In the FAB-MS spectra of 4 and 5 the molecular ions at $\mathrm{m} / \mathrm{z}=537(\mathrm{M}+\mathrm{Na})^{+}(\mathbf{4}), 539(\mathrm{M}+\mathrm{Na})^{+}(\mathbf{5})$ and the characteristic fragments at $\mathrm{m} / \mathrm{z}=497(\mathrm{M}+\mathrm{H}-18)^{+}(4)$ and $521(\mathrm{M}+\mathrm{Na}-18)^{+}(5)$ confirm the presence of the free hydroxyl group at the C-2 position of the glycerol moiety. In the negative ion FAB-MS spectra the molecular ions of the compounds 4 and 5 at $\mathrm{m} / \mathrm{z}=513(\mathrm{M}-$ $\mathrm{H})^{-}(4)$ and $515(\mathrm{M}-\mathrm{H})^{-}(5)$ and the presence of the fatty acid at $\mathrm{m} / \mathrm{z}=277\left(\mathrm{C}_{18} \mathrm{H}_{29} \mathrm{O}\right)^{-}(4)$ and $263\left(\mathrm{C}_{18} \mathrm{H}_{31} \mathrm{O}\right)^{-}(5)$ have been observed. Treatment of the compounds 4 and $\mathbf{5}$ with $\mathrm{NaOH}-\mathrm{MeOH}$ and $\mathrm{BF}_{3}-\mathrm{MeOH}$ as carried out for $\mathbf{1}$ provided the glyceryl $\beta$-D-galactopyranoside (6) as obtained from 1 and $\mathbf{2}$ and a mixture of fatty acid methyl esters. The glycerol galactoside obtained from the methanolysis of the compound 4 was shown to be identical with (2R)-1-O-glyceryl $\beta$-Dgalactopyranoside, which was obtained by the methanolysis of a galactosyl monoacylglycerol previously isolated by us from Euphorbia peplis L., on the basis of ${ }^{13} \mathrm{C}-\mathrm{NMR}$ and $[\alpha]_{\mathrm{D}}$ comparisons. ${ }^{9}$ The GC analysis of the fatty acid methyl esters indicated the presence only of a $\mathrm{C}_{18: 3 \omega 3}$ and $\mathrm{C}_{18: 2 \omega 6}$ fatty acid for the compounds $\mathbf{4}$ and 5, respectively. On the basis of the above spectral and chemical evidences, the structures of $\mathbf{4}$ and $\mathbf{5}$ were established as (2S)-3-O-(9, 12, 15-octadecatrienoyl)-glyceryl- $\beta$-D-galactopyranoside (4) and (2S)-3-O-(9, 12, octadecadienoyl)glyceryl- $\beta$-D-galactopyranoside (5). 
Table 1. ${ }^{1} \mathrm{H}-\mathrm{NMR},{ }^{13} \mathrm{C}-\mathrm{NMR}$ and COSY correlations data of 1-2

\begin{tabular}{|c|c|c|c|c|c|c|}
\hline \multirow[b]{2}{*}{$\mathrm{C}, \mathrm{H}$} & \multicolumn{3}{|c|}{1} & \multicolumn{3}{|c|}{2} \\
\hline & ${ }^{1} \mathrm{H}(\mathrm{m}, \mathrm{J} \mathrm{Hz})$ & ${ }^{13} \mathrm{C}$ & COSY & ${ }^{1} \mathrm{H}(\mathrm{m}, \mathrm{J} \mathrm{Hz})$ & ${ }^{13} \mathrm{C}$ & COSY \\
\hline $1^{\prime}$ & $4.80(\mathrm{~d}, 8.0)$ & 105.73 & $2^{\prime}$ & $4.85(\mathrm{~d}, 8.0)$ & 105.95 & $2^{\prime}$ \\
\hline $2^{\prime}$ & 4.50 (m, obs) & 72.41 & $1^{\prime}, 3^{\prime}$ & 4.53 (m, obs) & 72.58 & $1^{\prime}, 3^{\prime}$ \\
\hline $3^{\prime}$ & 4.11 (dd, 9.5, 3.0) & 77.24 & $2^{\prime}, 4^{\prime}$ & 4.10 (dd, 9.5, 3.0) & 77.47 & $2^{\prime}, 4^{\prime}$ \\
\hline $4^{\prime}$ & 4.39 (d, 3.4) & 70.17 & $3^{\prime}, 5^{\prime}$ & $4.42(\mathrm{~d}, 3.4)$ & 70.37 & $3^{\prime}, 5^{\prime}$ \\
\hline $5^{\prime}$ & 4.14 (dd, 5.8, 5.5) & 75.38 & $4^{\prime}, 6^{\prime}$ & $4.16(\mathrm{dd}, 5.8,5.5)$ & 75.55 & $4^{\prime}, 6^{\prime}$ \\
\hline $6^{\prime}$ & 4.62 (m, obs) & 62.39 & $5^{\prime}$ & 4.64 (m, obs) & 62.55 & $5^{\prime}$ \\
\hline \multirow[t]{2}{*}{1} & $4.05(\mathrm{dd}, 10.7,5.0)$ & 68.31 & 2 & $4.05(\mathrm{dd}, 10.7,5.0)$ & 68.37 & 2 \\
\hline & $4.31(\mathrm{dd}, 10.7,5.2)$ & & & $4.38(\mathrm{dd}, 10.7,5.2)$ & & \\
\hline 2 & $5.64(\mathrm{~m})$ & 71.24 & 1,3 & $5.64(\mathrm{~m})$ & 71.27 & 1,3 \\
\hline \multirow[t]{2}{*}{3} & 4.37 (dd, 11.9, 5.2) & 63.64 & 2 & 4.40 (dd, 11.9, 5.2) & 63.57 & 2 \\
\hline & $4.44(\mathrm{dd}, 11.9,3.1)$ & & & $4.48(\mathrm{dd}, 11.9,3.1)$ & & \\
\hline \multirow[t]{2}{*}{$\mathrm{C}=\mathrm{O}$} & - & 173.41 & & - & 173.29173 .45 & \\
\hline & & 173.70 & & & & \\
\hline \multirow[t]{2}{*}{$\mathrm{OCOCH}_{2}$} & $2.35(t, 7.2)$ & 34.46 & $3-\underline{\mathrm{H}}_{2}$ & $2.35(t, 7.2)$ & 34.47 & $3-\underline{\mathrm{H}}_{2}$ \\
\hline & & 34.74 & & & 34.71 & \\
\hline $\mathrm{OCOCH}_{2} \underline{\mathrm{CH}}_{2}$ & $1.80(\mathrm{~m})$ & 25.51 & $2-\underline{\mathrm{C}}_{2}, 4-\underline{\mathrm{H}}_{2}$ & $1.62(\mathrm{~m})$ & 25.51 & $\begin{array}{c}2-\underline{\mathrm{CH}}_{2}, 4- \\
\mathrm{C}_{\underline{H}_{2}}\end{array}$ \\
\hline $8-\underline{\mathrm{CH}}_{2}-\mathrm{CH}=$ & $2.10(\mathrm{~m})$ & 27.74 & $\mathrm{C} \underline{\mathrm{H}}=, 7-\mathrm{C}_{2}$ & & & \\
\hline $17-\mathrm{CH}_{2}-\mathrm{CH}=$ & $2.05(\mathrm{~m})$ & 21.15 & $\mathrm{C}_{3}, \underline{\mathrm{CH}}=$ & & & \\
\hline \multirow[t]{4}{*}{$\mathrm{CH}=\mathrm{CH}$ cis } & 5.35-5.45 (m) & 127.75 & $\mathrm{C}_{2} \mathrm{CH}$ & & & \\
\hline & & 130.75 & & & & \\
\hline & & 128.32 & & & & \\
\hline & & 132.34 & & & & \\
\hline \multirow[t]{2}{*}{$=\mathrm{CHCH}_{2} \mathrm{CH}=$} & 2.90 (dd, 7.2, 7.2) & 26.18 & $\mathrm{C} \underline{\mathrm{H}}=$ & & & \\
\hline & & 26.30 & & & & \\
\hline \multirow[t]{2}{*}{$-\mathrm{CH}_{2-}$} & $1.25(\mathrm{~m})$ & $29.60-$ & & $1.30(\mathrm{~m})$ & 29.65-29.92 & $\mathrm{C}_{2}$ \\
\hline & & 29.81 & & & & \\
\hline 7- $\mathrm{CH}_{2}$ & $1.30(\mathrm{~m})$ & 30.14 & 8- $\mathrm{CH}_{2} \mathrm{CH}_{2}$ & $0.85(t, 7.1)$ & 14.6 & $\mathrm{CH}_{2}$ \\
\hline 14- $\mathrm{CH}_{2}$ & - & - & - & 1.26 (m) & 31.70 & \\
\hline $15-\mathrm{CH}_{2}$ & - & - & - & $1.26(\mathrm{~m})$ & 22.95 & $14-\underline{\mathrm{CH}}_{2}, \underline{\mathrm{CH}}_{3}$ \\
\hline $\mathrm{CH}_{3}$ & $0.96(t, 7.0)$ & 14.83 & $17-\mathrm{CH}_{2}$ & 0.85 (br t, 6.7) & 14.77 & $15-\underline{\mathrm{H}}_{2}$ \\
\hline
\end{tabular}

Comparative analysis of the fatty acid distributions of the five glyceroglycolipids reveals that the content in the plant and proportion of unsaturated fatty acids of glyceroglycolipids 1, 3-5 are higher than those of $\mathbf{2}$. In conclusion, we have characterized five glyceroglycolipids with unprecedented acyl distributions from Euphorbia nicaeensis All. The glyceroglycolipids $\mathbf{2}$ and $\mathbf{5}$ 
are new since they have been isolated for the first time from Euphorbiaceae. The five glyceroglycolipids are unique in both, their low content in the plant and high proportion of unsaturated fatty acids. Therefore, their physicochemical properties and biological function may be of interest.

Table 2. ${ }^{1} \mathrm{H}$-NMR, ${ }^{13} \mathrm{C}-\mathrm{NMR}$ and COSY correlations data of $\mathbf{3}$

\begin{tabular}{|c|c|c|c|}
\hline \multirow[b]{2}{*}{ C, $\mathrm{H}$} & \multicolumn{3}{|c|}{3} \\
\hline & ${ }^{1} \mathrm{H}(\mathrm{m}, \mathrm{J} \mathrm{Hz})$ & ${ }^{13} \mathrm{C}$ & COSY \\
\hline $1^{\prime}$ & $4.75(\mathrm{~d}, 7.9)$ & 105.25 & $2^{\prime}$ \\
\hline $2^{\prime}$ & 4.42 (m, obs) & 71.93 & $1^{\prime}, 3^{\prime}$ \\
\hline $3^{\prime}$ & 4.13 (dd, 9.8, 3.1) & 74.81 & $2^{\prime}, 4^{\prime}$ \\
\hline $4^{\prime}$ & 4.36 (m, obs) & 67.97 & $3^{\prime}, 5^{\prime}$ \\
\hline $5^{\prime}$ & 4.17 (dd, 6.2, 5.8) & 74.32 & $4^{\prime}, 6^{\prime}$ \\
\hline $6^{\prime}$ & 4.68 (m, obs) & 70.11 & $5^{\prime}$ \\
\hline 1" & $5.45(\mathrm{~d}, 3.7)$ & 101.11 & $2 "$ \\
\hline $2 "$ & 4.47-4.54 (m, obs) & 69.61 & 1", 3" \\
\hline 3" & 4.64 (m, obs) & 71.47 & 2", 4" \\
\hline $4 "$ & 4.54 (m, obs) & 70.38 & 3", 5" \\
\hline $5 "$ & 4.55 (m, obs) & 72.65 & 4", 6" \\
\hline 6" & 4.34-4.44 (m, obs) & 62.32 & $5 "$ \\
\hline \multirow[t]{2}{*}{1} & 4.02 (dd, 12.1, 3.0) & 67.77 & 2 \\
\hline & 4.32 (dd, 12.1, 6.0) & & \\
\hline 2 & $5.63(\mathrm{~m})$ & 70.11 & 1,3 \\
\hline \multirow[t]{2}{*}{3} & 4.46 (dd, 9.0, 5.2) & 63.14 & 2 \\
\hline & 4.58 (dd, 9.0, 3.1) & & \\
\hline \multirow[t]{2}{*}{$\mathrm{C}=\mathrm{O}$} & - & 172.95 & \\
\hline & & 172.79 & \\
\hline $\mathrm{OCOCH}_{2}$ & $2.30(t, 7.4)$ & 34.3133 .97 & $3-\underline{\mathrm{CH}}_{2}$ \\
\hline $\mathrm{OCOCH}_{2} \underline{\mathrm{CH}}_{2}$ & 1.65 (m) & 25.00 & $2-\underline{\mathrm{C}}_{2}, 4-\underline{\mathrm{C}}_{2}$ \\
\hline $8-\underline{\mathrm{CH}}_{2}-\mathrm{CH}=$ & $2.08(\mathrm{~m})$ & 27.31 & $\mathrm{C} \underline{\mathrm{H}}=, 7-\mathrm{CH}_{2}$ \\
\hline $17-\mathrm{CH}_{2}-\mathrm{CH}=$ & $2.04(\mathrm{~m})$ & 20.64 & $\mathrm{C}_{\mathrm{H}_{3}}, \mathrm{C} \underline{\mathrm{H}}=$ \\
\hline \multirow[t]{3}{*}{$\mathrm{CH}=\mathrm{CH}$ cis } & $5.48-5.55(\mathrm{~m})$ & 127.27130 .28 & $\mathrm{C}_{2} \mathrm{CH}$ \\
\hline & & 127.83131 .81 & \\
\hline & & 128.35 & \\
\hline$=\mathrm{CHCH}_{2} \mathrm{CH}=$ & 2.90 (dd, 7.4, 7.4) & 25.6825 .79 & $\mathrm{C} \underline{\mathrm{H}}=$ \\
\hline$-\mathrm{CH}_{2^{-}}$ & $1.20(\mathrm{~m})$ & 29.11-29.29 & \\
\hline 7- $\mathrm{CH}_{2}$ & 1.30 (m) & 29.69 & $8-\underline{\mathrm{H}}_{2} \mathrm{CH}_{2}$ \\
\hline $\mathrm{CH}_{3}$ & $0.95(\mathrm{t}, 7.1)$ & 14.27 & $17-\mathrm{CH}_{2}$ \\
\hline
\end{tabular}


Table 3. ${ }^{1} \mathrm{H}-\mathrm{NMR},{ }^{13} \mathrm{C}-\mathrm{NMR}$ and COSY correlations data of 4-5

\begin{tabular}{|c|c|c|c|c|c|c|}
\hline \multirow[b]{2}{*}{$\mathrm{C}, \mathrm{H}$} & \multicolumn{3}{|c|}{4} & \multicolumn{3}{|c|}{5} \\
\hline & ${ }^{1} \mathrm{H}(\mathrm{m}, \mathrm{J} \mathrm{Hz})$ & ${ }^{13} \mathrm{C}$ & COSY & ${ }^{1} \mathrm{H}(\mathrm{m}, \mathrm{J} \mathrm{Hz})$ & ${ }^{13} \mathrm{C}$ & COSY \\
\hline $1^{\prime}$ & $4.85(\mathrm{~d}, 7.9)$ & 105.89 & $2^{\prime}$ & $4.90(\mathrm{~d}, 7.9)$ & 105.96 & $2^{\prime}$ \\
\hline $2^{\prime}$ & 4.39 (m, obs) & 72.73 & $1^{\prime}, 3^{\prime}$ & 4.40 (m, obs) & 72.63 & $1^{\prime}, 3^{\prime}$ \\
\hline $3^{\prime}$ & 4.11 (dd, 9.6, 3.4) & 77.22 & $2^{\prime}, 4^{\prime}$ & 4.20 (dd, 9.6, 3.1) & 77.18 & $2^{\prime}, 4^{\prime}$ \\
\hline $4^{\prime}$ & $4.19(\mathrm{~d}, 3.4)$ & 69.16 & $3^{\prime}, 5^{\prime}$ & $4.50(\mathrm{~d}, 3.1)$ & 69.05 & $3^{\prime}, 5^{\prime}$ \\
\hline $5^{\prime}$ & 4.15 (dd, 7.5, 5.3) & 75.46 & $4^{\prime}, 6^{\prime}$ & $4.10(\mathrm{dd}, 7.5,5.2)$ & 75.40 & $4^{\prime}, 6^{\prime}$ \\
\hline $6^{\prime}$ & 4.52 (m, obs) & 62.41 & $5^{\prime}$ & 4.40 (m, obs) & 62.39 & $5^{\prime}$ \\
\hline \multirow[t]{2}{*}{1} & $4.09(\mathrm{dd}, 10.4,5.1)$ & 72.27 & 2 & $4.16(\mathrm{dd}, 10.4,5.1)$ & 72.32 & 2 \\
\hline & $4.34(\mathrm{dd}, 10.4,5.2)$ & & & $4.42(\mathrm{dd}, 10.4,5.2)$ & & \\
\hline 2 & $4.62(\mathrm{~m})$ & 70.25 & 1,3 & $4.66(\mathrm{~m})$ & 70.28 & 1,3 \\
\hline 3 & $4.57(\mathrm{~m})$ & 66.80 & 2 & $4.56(\mathrm{~m})$ & 66.70 & 2 \\
\hline $\mathrm{C}=\mathrm{O}$ & - & 173.78 & & - & 173.57 & \\
\hline $\mathrm{OCOCH}_{2}$ & $2.35(t, 7.1)$ & 34.47 & 3- $\underline{\mathrm{CH}}_{2}$ & $2.30(t, 7.4)$ & 34.38 & $3-\underline{\mathrm{H}}_{2}$ \\
\hline $\mathrm{OCOCH}_{2} \underline{\mathrm{CH}}_{2}$ & $1.60(\mathrm{~m})$ & 25.42 & $\begin{array}{c}2-\underline{\mathrm{CH}}_{2}, 4- \\
\mathrm{C}^{\mathrm{H}_{2}}\end{array}$ & $1.60(\mathrm{~m})$ & 25.33 & $\begin{array}{c}2-\underline{\mathrm{CH}}_{2}, 4- \\
\mathrm{CH}_{2}\end{array}$ \\
\hline $8-\underline{\mathrm{CH}}_{2}-\mathrm{CH}=$ & $2.05(\mathrm{~m})$ & 27.74 & $\mathrm{C} \underline{\mathrm{H}}=, 7-\underline{\mathrm{CH}}_{2}$ & - & - & - \\
\hline $17-\underline{\mathrm{CH}}_{2}-\mathrm{CH}=$ & $2.02(\mathrm{~m})$ & 20.89 & $\mathrm{C}_{3}, \mathrm{C} \underline{\mathrm{H}}=$ & - & - & - \\
\hline$\underline{\mathrm{CH}}_{2}-\mathrm{CH}=$ & - & - & & $2.05(\mathrm{~m})$ & 27.58 & $\mathrm{C} \underline{\mathrm{H}}=, \underline{\mathrm{CH}}_{2}$ \\
\hline \multirow[t]{5}{*}{$\mathrm{CH}=\mathrm{CH}$ cis } & $5.50-5.55(\mathrm{~m})$ & 127.72 & $\mathrm{C}_{2}{ }_{2} \mathrm{CH}$ & $5.48-5.56(\mathrm{~m})$ & 128.12130 .46 & $\mathrm{C}_{2}$ \\
\hline & & 130.76 & & & 128.39130 .59 & \\
\hline & & 128.48 & & & & \\
\hline & & 132.18 & & & & \\
\hline & & 128.95 & & & & \\
\hline \multirow[t]{2}{*}{$=\mathrm{CHCH}_{2} \mathrm{CH}=$} & 2.95 (dd, 7.4, 7.4) & 26.03 & $\mathrm{CH}=$ & 2.95 (dd, 6.6, 6.6) & 25.98 & $\mathrm{CH}=$ \\
\hline & & 26.25 & & & & \\
\hline$-\mathrm{CH}_{2-}^{-}$ & $1.25(\mathrm{~m})$ & $\begin{array}{l}29.10- \\
29.19\end{array}$ & & $1.30(\mathrm{~m})$ & 29.44-29.95 & $\mathrm{C}_{2}$ \\
\hline 7- $\mathrm{CH}_{2}$ & $1.30(\mathrm{~m})$ & 29.61 & $8-\underline{\mathrm{H}}_{2} \mathrm{CH}_{2}$ & - & - & \\
\hline 16- $\mathrm{CH}_{2}$ & - & - & - & $1.26(\mathrm{~m})$ & 31.80 & $\mathrm{CH}_{2}$ \\
\hline $17-\mathrm{CH}_{2}$ & - & & & $1.26(\mathrm{~m})$ & 22.93 & $16-\mathrm{CH}_{2}, \mathrm{CH}_{3}$ \\
\hline $\mathrm{CH}_{3}$ & $0.94(t, 7.5)$ & 14.54 & $17-\mathrm{CH}_{2}$ & 0.85 (br t, 6.8) & 14.25 & $17-\mathrm{CH}_{2}$ \\
\hline
\end{tabular}

\section{Pharmacology}

The individual isolated glyceroglycolipids 1-5 have been tested for their anti-inflammatory activity evaluated as inhibition of the Croton oil-induced ear oedema in mice. The results on the topical anti-inflammatory activity in vivo of the compounds 1-5 and of indomethacin are reported in Table 4 . The compound $\mathbf{1}$, administered at the same single dose level $\left(1 \mu \mathrm{M} / \mathrm{cm}^{2}\right)$, revealed a 
significant anti-inflammatory activity, reducing the oedematous response by $92 \%$ whereas $0.25 \mu \mathrm{M} / \mathrm{cm}^{2}$ of the reference drug induced about 50\% oedema reduction. The compounds 2-5 exhibited a significant anti-inflammatory activity with percentages of oedema reduction of $65 \%$ (2), $82.9 \%(3)$ and $61.0 \%(4,5)$ respectively.

Table 4. Anti-inflammatory activity of compounds 1-5

\begin{tabular}{lcccc}
\hline Substance & $\begin{array}{c}\text { Dose } \\
(\mu \mathrm{M})\end{array}$ & $\mathrm{N}^{+}$ & $\begin{array}{c}\text { Oedema (mg) } \\
\mathrm{M} \pm \text { S. E. }\end{array}$ & ++ \\
\hline & & & & \\
Control & -- & 10 & $7.2 \pm 0.3$ & -- \\
$\mathbf{1}$ & 1.00 & 10 & $0.6 \pm 0.1$ & 92.0 \\
$\mathbf{2}$ & 1.00 & 10 & $2.3 \pm 0.5$ & 65.0 \\
$\mathbf{3}$ & 1.00 & 10 & $1.2 \pm 0.3$ & 82.9 \\
$\mathbf{4}$ & 1.00 & 10 & $2.4 \pm 0.5$ & 61.0 \\
$\mathbf{5}$ & 1.00 & 10 & $2.4 \pm 0.5$ & 61.0 \\
Indomethacin & 0.25 & 10 & $3.6 \pm 0.3$ & 48.6 \\
\hline
\end{tabular}

$\mathrm{p}<0.05$ at the Student's test; ${ }^{+}$: Number of animals; ${ }^{++}: \%=$ Percentage of oedema reduction.

\section{Experimental Section}

General Procedures. NMR-spectroscopy: nuclear magnetic resonance spectra were recorded with a Varian Unity 400 spectrometer and a Varian Gemini $200 \mathrm{MHz}$ spectrometer. ${ }^{13} \mathrm{C}-\mathrm{NMR}$ : 100.4 MHz, Unity 400 spectrometer. NMR spectra were obtained by using $\mathrm{C}_{5} \mathrm{D}_{5} \mathrm{~N}$ as solvent; chemical shifts are expressed as $\delta$ units (ppm) relative to tetramethylsilane (TMS) as internal standard. The abbreviations s, d, dd, t, q, m and br s refer to singlet, doublet, doublet of doublet, triplet, quartet, multiplet and broad singlet respectively. The PI-FD spectra $\left(\mathrm{CH}_{2} \mathrm{Cl}_{2}\right)$ were obtained using double-focusing MAT 95 mass spectrometer. FAB-MS: Kratos MS 80 RFA. FAB-MS: (8 Kv, Xe, methanol as solvent and glycerol matrix + $\mathrm{NaCl}$ ). Electrospray analysis: API Perkin Elmer (voltage +5600 with orifice 90 and / or 120). Silica gel column chromatography: Kieselgel 60 (230-400 Mesh, 60 A Merck). FT-IR spectra: Jasco IR-700 infrared spectrophotometer. Flash chromatography reversed-phase: LiChroprep RP-18 (40, $63 \mu \mathrm{m}$, Merck). All solvents were distilled before use. TLC: Kieselgel $60 \mathrm{~F}_{254}(20$ x $20 \mathrm{~cm}$; $0.2 \mathrm{~mm}$, Merck). HPTLC: HPTLC-fertigplatten RP-18 F 254 (10 x 10 cm, Merck).

The fatty acid composition of 1-5 was released as methyl esters by the official A.O.A.C. methylation procedure, and analysed by gas chromatography (GLC). ${ }^{14}$ A Shimadzu GC 14A (Kyoto, Japan) instrument, equipped with a split/splitless injector (1:20) and a flame ionization detector, was used. A SP 2330 fused silica capillary column, 30 m x 0.32 mm I.D., $0.20 \mu \mathrm{m}$ film thickness (Supelco, Inc., Bellefonte, PA) was employed. The chromatographic conditions were: 
column temperature was programmed from $150{ }^{\circ} \mathrm{C}$ (kept for $2 \mathrm{~min}$ ) to $250{ }^{\circ} \mathrm{C}$ at $10{ }^{\circ} \mathrm{C} / \mathrm{min}$ (maintained for $5 \mathrm{~min}$ ), injector and detector temperature $280{ }^{\circ} \mathrm{C}$, carrier gas (helium) and flow rate $2.0 \mathrm{ml} / \mathrm{min}$.

Separation of glyceroglycolipids 1-5. E. nicaeensis All. (1 Kg) was harvested in July 2001 in Carso Triestino (Pesek); Italy. The voucher specimen of the plant material has been deposited at the Herbarium of the Department of Biology (TSB) of the University of Trieste (Italy). The stems and the leaves of the plant were cut and extracted with $\mathrm{MeOH}$ (3l) for 7 days. The extract was filtered, methanol was concentrated in vacuo to give a $\mathrm{MeOH}$ extract (30.5 g), which was chromatographed on silica gel $\left(\mathrm{CHCl}_{3}, \mathrm{MeOH}, \mathrm{CHCl}_{3}: \mathrm{MeOH} / 5: 1 / \mathrm{v}: \mathrm{v}\right.$ and $\mathrm{CHCl}_{3}: \mathrm{MeOH} /$ 5:2 /v:v). The fraction C eluted with $\mathrm{CHCl}_{3}: \mathrm{MeOH}(5: 1 / \mathrm{v}: \mathrm{v})$ was concentrated in vacuo and submitted to reversed phase column flash chromatography using $\mathrm{MeOH}$ as eluent to afford the compounds 1 (55 mg) and 2 (73 mg) each showed a single spot on reversed phase TLC (MeOH).

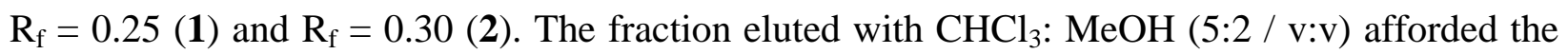
compound 3 [ $150 \mathrm{mg} ; \mathrm{R}_{\mathrm{f}}$ (Silica gel, $\mathrm{CHCl}_{3}: \mathrm{MeOH} / 5: 2$ /v:v) = 0.52] and the fraction E. The fraction $\mathrm{E}$ was concentrated in vacuo and submitted to reversed phase column flash chromatography using $\mathrm{MeOH}$ as eluent to afford the compounds 4 (85 mg) and 5 (60 mg) each showed a single spot on reversed phase TLC (MeOH). $R_{f}=0.55$ (4) and $R_{f}=0.59$ (5) (Scheme 1).

(2S)-2,3-O-Di-(9, 12, 15-Octadecatrienoyl)-glyceryl- $\beta$-D-galactopyranoside (1). FT-IR (film) $\mathrm{cm}^{-1}$ : 3595 (hydroxyl), 1719 (ester). Positive-ion FAB MS: m/z = $797(\mathrm{M}+\mathrm{Na}, 56 \%)^{+}, 613(\mathrm{M}+$ $\mathrm{H}-162,22 \%)^{+}, 595(\mathrm{M}+\mathrm{H}-180,48 \%)^{+}, 519(\mathrm{M}+\mathrm{Na}-278,7 \%)^{+}, 335\left(\mathrm{C}_{18} \mathrm{H}_{29} \mathrm{O}+74,85 \%\right)^{+}$, $261\left(\mathrm{C}_{18} \mathrm{H}_{29} \mathrm{O}, 16 \%\right)^{+}$. Negative-ion FAB MS: m/z= $773(\mathrm{M}-\mathrm{H}, 55 \%)^{-}, 277\left(\mathrm{C}_{18} \mathrm{H}_{29} \mathrm{O}_{2}, 100 \%\right)^{-}$. ${ }^{1} \mathrm{H}$ and ${ }^{13} \mathrm{C}$ NMR data are reported in Table 1.

(2S)-2,3-O-Di-(Hexadecanoyl)-glyceryl- $\beta$-D-galactopyranoside (2). FT-IR (film) $\mathrm{cm}^{-1}$ : 3597 (hydroxyl), 1720 (ester). Positive-ion FAB MS: m/z = $753(\mathrm{M}+\mathrm{Na}, 53 \%)^{+}, 731(\mathrm{M}+\mathrm{H}, 18 \%)^{+}$, $521(\mathrm{M}+\mathrm{H}-180,75 \%)^{+}, 497(\mathrm{M}+\mathrm{Na}-256,14 \%)^{+}, 313\left(\mathrm{C}_{16} \mathrm{H}_{31} \mathrm{O}+74,43 \%\right)^{+}, 239\left(\mathrm{C}_{16} \mathrm{H}_{31} \mathrm{O}\right.$, $16 \%)^{+}$. Negative-ion FAB MS: m/z= $729(\mathrm{M}-\mathrm{H}, 54 \%)^{-}, 279\left(\mathrm{C}_{16} \mathrm{H}_{31} \mathrm{O}_{2}, 75 \%\right)^{-} .{ }^{1} \mathrm{H}$ and ${ }^{13} \mathrm{C}$ NMR data are reported in Table 1.

(2S)-2,3-O-Di-(9,12,15-Octadecatrienoyl)-glyceryl-6-o-( $\alpha$-D-galactopyranosyl)- $\beta$-D-galactopyranoside (3). FT-IR (film) $\mathrm{cm}^{-1}$ : 3587 (hydroxyl), 1650 (ester). Positive-ion FAB MS: $\mathrm{m} / \mathrm{z}=$ $959(\mathrm{M}+\mathrm{Na}, 100 \%)^{+}, 937(\mathrm{M}+\mathrm{H}, 69 \%)^{+}, 595(\mathrm{M}+\mathrm{Na}-364,25 \%)^{+}, 335\left(\mathrm{C}_{18} \mathrm{H}_{29} \mathrm{O}+74\right.$, $72 \%)^{+}$. Negative-ion FAB MS: $\mathrm{m} / \mathrm{z}=935(\mathrm{M}-\mathrm{H}, 84 \%)^{-}, 277\left(\mathrm{C}_{18} \mathrm{H}_{29} \mathrm{O}, 22 \%\right)^{-} .{ }^{1} \mathrm{H}$ and ${ }^{13} \mathrm{C}$ NMR data are reported in Table 2.

(2S)-3-O-(9, 12, 15-Octadecatrienoyl)-glyceryl- $\beta$-D-galactopyranoside (4). FT-IR (film) $\mathrm{cm}^{-1}$ : 3450 (hydroxyl), 1720 (ester). Positive-ion FAB MS: m/z = $537(\mathrm{M}+\mathrm{Na}, 60 \%)^{+}, 515(\mathrm{M}+\mathrm{H}$, $23 \%)^{+}, 497(\mathrm{M}+\mathrm{H}-18,10 \%)^{+}, 335\left(\mathrm{C}_{18} \mathrm{H}_{29} \mathrm{O}+74,72 \%\right)^{+}$. Negative-ion FAB MS: m/z= $513(\mathrm{M}$ $-\mathrm{H}, 68 \%)^{-}, 277\left(\mathrm{C}_{18} \mathrm{H}_{29} \mathrm{O}, 100 \%\right)^{-}$. ESI-MS: $\mathrm{m} / \mathrm{z}=537(\mathrm{M}+\mathrm{Na}, 100 \%)^{+}, 497(\mathrm{M}+\mathrm{H}-18$, $7.5 \%)^{+}, 317(\mathrm{M}+\mathrm{H}-180-18,65 \%)^{+} .{ }^{1} \mathrm{H}$ and ${ }^{13} \mathrm{C}$ NMR data are reported in Table 3. 
(2S)-3-O-(9, 12-Octadecadienoyl)-glyceryl- $\beta$-D-galactopyranoside (5). FT-IR (film) $\mathrm{cm}^{-1}$ : 3460 (hydroxyl), 1720 (ester). Positive-ion FAB MS: m/z = $539(\mathrm{M}+\mathrm{Na}, 68 \%)^{+}, 517(\mathrm{M}+\mathrm{H}$, $13 \%)^{+}, 521(\mathrm{M}+\mathrm{Na}-18,8 \%)^{+}, 337\left(\mathrm{C}_{18} \mathrm{H}_{31} \mathrm{O}+74,75 \%\right)^{+}, 263\left(\mathrm{C}_{18} \mathrm{H}_{31} \mathrm{O}, 15 \%\right)^{+}$. Negative-ion FAB MS: $\mathrm{m} / \mathrm{z}=515(\mathrm{M}-\mathrm{H}, 68 \%)^{-}, 279\left(\mathrm{C}_{18} \mathrm{H}_{31} \mathrm{O}_{2}, 100 \%\right)^{-} .{ }^{1} \mathrm{H}$ and ${ }^{13} \mathrm{C}$ NMR data are reported in Table 3.

Methanolysis of compounds 1-5. $50 \mathrm{mg}$ of 1-5 were heated with $4 \mathrm{ml}$ of a $0.5 \mathrm{~N}$ solution of $\mathrm{NaOH}$ in $\mathrm{CH}_{3} \mathrm{OH}$ reflux for 20 min. The reaction mixture was employed in the next step without further purification. A solution of 1-5, after alkaline treatment, was heated with $5 \mathrm{ml}$ of a solution of $\mathrm{BF}_{3} / \mathrm{CH}_{3} \mathrm{OH}$ reflux for 2 min. The reaction mixture was extracted with $n$-heptane ( $2 \mathrm{ml}$ ) reflux for $1 \mathrm{~min}$ and quenched with a saturated $\mathrm{NaCl}$ solution; the $n$-heptane phase, dried over $\mathrm{Na}_{2} \mathrm{SO}_{4}$, was filtered and evaporated under reduced pressure to give fatty acid methyl esters, analyzed directly by GC. The hydrophylic portion was concentrated under reduced pressure, filtered and the evaporation of the remaining solvent yielded a residue, which was purified by $\mathrm{SiO}_{2}$ column chromatography $\left(\mathrm{CHCl}_{3}-\mathrm{MeOH}\right)$ to furnish 6 (9.5 mg) and 7 (8 mg).

6. White powder, $[\alpha]_{\mathrm{D}}-8^{\circ}\left(\mathrm{c}=0.7, \mathrm{H}_{2} \mathrm{O}, 25^{\circ}\right) .{ }^{1} \mathrm{H}-\mathrm{NMR}\left(400 \mathrm{MHz}, \mathrm{C}_{5} \mathrm{D}_{5} \mathrm{~N}\right.$ containing 1 drop of $\mathrm{D}_{2} \mathrm{O}$ ): $\delta=4.87$ ppm (d, 1H, H-1', J = $7.7 \mathrm{~Hz}$ ), 4.49 (dd, 1H, H-2', J = 7.7, 9.4 Hz), 4.13 (dd, 1H, H-3', J = 9.4, 3.4 Hz), 4.50 (d, 1H, H-4', J = 3.4 Hz), 4.06 (dd, 1H, H-5', J = 6.3, $5.3 \mathrm{~Hz}$ ), 4.40 (m, 2H, 2H-6'), 4.44 (dd, 1H, H-1 a $\mathrm{J}=10.0,6.1 \mathrm{~Hz}$ ), 4.22 (dd, 1H, H-1 b, J = 10.0, 4.2 Hz), 4.40 (m, 1H, H-2), 4.10 (d, 1H, H-3, $\mathrm{J}=4.4 \mathrm{~Hz}$ ), 4.09 (d, 1H, H-3, $\mathrm{J}=5.4 \mathrm{~Hz}$ ). ${ }^{13} \mathrm{C} \mathrm{NMR}$ (100.4 MHz, $\mathrm{C}_{5} \mathrm{D}_{5} \mathrm{~N}$ containing 1 drop of $\left.\mathrm{D}_{2} \mathrm{O}\right): \delta=104.9 \mathrm{ppm}\left(\mathrm{C}-1^{\prime}\right), 72.6$ (C-2'), 77.3 (C-3'), 70.4 (C-4'), 76.0 (C-5'), 62.4 (C-6'), 72.3 (C-1), 70.9 (C-2), 65.2 (C-3). FAB-MS: m/z = 277 ( M $+\mathrm{Na})^{+}$.

7. White powder, $[\alpha]_{\mathrm{D}}+80^{\circ}\left(\mathrm{c}=0.6, \mathrm{H}_{2} \mathrm{O}, 25^{\circ}\right) .{ }^{1} \mathrm{H}-\mathrm{NMR}\left(400 \mathrm{MHz}, \mathrm{C}_{5} \mathrm{D}_{5} \mathrm{~N}\right): \delta=5.50 \mathrm{ppm}(\mathrm{d}$, $1 \mathrm{H}, \mathrm{H}-1$ ", J = 3.7 Hz), 4.80 (d, 1H, H-1', J = 7.7 Hz), 4.59 (dd, 1H, H-2", J = 3.6, $10.0 \mathrm{~Hz}$ ), 4.61 (dd, 1H, H-3", J = 10.0, 3.6 Hz), 4.52 (m, 2H, H-4', H-1 ) , 4.46 (m, 1H, H-2'), 4.40 (m, 2H, H-4", H-2), 4.27 (m, 1H, H-1 ${ }_{b}$ ), 4.24 (m, 2H, H-5", H-5'), 4.14 (m, 1H, H-3'), 4.10 (m, 3H, H-6", H-6', H-3). ${ }^{13} \mathrm{C}$ NMR (100.4 MHz, $\left.\mathrm{C}_{5} \mathrm{D}_{5} \mathrm{~N}\right): \delta=105.6$ ppm (C-1'), 101.0 (C-1"), 75.1 (C-3'), 74.5 (C5'), 73.0 (C-5"), 72.3 (C-2'), 72.0 (C-3"), 70.9 (C-6'), 71.0 (C-4"), 70.5 (C-2), 70.3 (C-2"), 70.6 (C-1), 68.2 (C-4'), 63.8 (C-3), 62.3 (C-6").

\section{Topical anti-inflammatory activity}

The topical anti-inflammatory activity was evaluated as inhibition of the Croton oil-induced ear oedema in mice. ${ }^{15}$ The experimental design was approved by the ethical committee of the University of Trieste. Male CD-1 mice (28-32 g; Harlan Italy, S. Pietro al Natisone, Italy) were anaesthetised with ketamine hydrochloride (145 mg/Kg, intraperitoneally; Virbac, Milano, Italy). Cutaneous inflammation was induced on the inner surface of the right ear (surface: about $1 \mathrm{~cm}^{2}$ ) of anaesthetised mice by application of $15 \mu \mathrm{l}$ of an acetone solution containing $80 \mu \mathrm{g}$ of Croton oil. Control animals received only the irritant solution whereas the other animals received the solution containing both the irritant and the substance under testing. Six hours later, mice were 
sacrificed and a plug ( $6 \mathrm{~mm} \varnothing$ ) was removed from both the treated (right) and the untreated (left) ears. The oedematous response was measured as the weight difference between the two plugs. The anti-inflammatory activity was expressed as percentage of the oedema reduction in treated mice compared to the control mice. As a reference, the non steroidal anti-inflammatory drug (NSAID) indomethacin was used. Indomethacin was dissolved in acetone, the compounds 1-5 were dissolved in acetone : EtOH : $\mathrm{H}_{2} \mathrm{O}(1: 1: 1 / \mathrm{v}: \mathrm{v})$.

Statistical analysis. The pharmacological data were analysed by the Student's $t$-test, and a probability level lower than 0.05 was considered as significant.

\section{References}

1. Hecker, E. Pure and Applied Chemistry 1977, 49, 1423.

2. Evans, F. J.; Soper, C. J. Lloydia 1978, 41, 193.

3. Öksikz, S.; Shich, H. L.; Pezzato, J. M.; Ozhatay; N.; Cordeli, G. A. Planta Medica 1993, 59, 472.

4. Cateni, F.; Zilic, J.; Falsone, G.; Hollan, F.; Frausin, F.; Scarcia, V. Il Farmaco 2003, 58, 809.

5. Hemmers, H.; Gülz, P.G. Phytochemistry 1986, 25, 2103.

6. Cateni, F.; Falsone, G.; Zilic, J. Mini Reviews in Medicinal Chemistry 2003, 3, 425.

7. Cateni, F.; Zilic, J.; Falsone, G.; Kralj, B.; Della Loggia, R.; Sosa, S. Pharm. Pharmacol. Lett. 2001, 2, 53.

8. Cateni, F.; Falsone, G.; Vitrotti, E.; Zilic, J.; Birkofer, L.; Della Loggia, R.; Sosa, S. Pharm. Pharmacol. Lett. 2000, 2, 65.

9. Cateni, F.; Zilic, J.; Falsone, G.; Kralj, B.; Tubaro, A.; Sosa, S. Pharm. Pharmacol. Lett. 2001, 2, 49.

10. Kitagawa, I.; Hayashi, K.; Kobayashi, M. Chem. Pharm. Bull. 1989, 37, 849.

11. Colombo, D.; Compostella, F.; Ronchetti, F.; Scala, A.; Toma, L., Kuchide, M.; Tokuda, H.; Nishino, H. Cancer Lett. 2000, 161, 201.

12. Colombo, D.; Compostella, F.; Ronchetti, F.; Scala, A.; Tokuda, H.; Nishino, H. Eur. J. Med. Chem. 2001, 36, 691.

13. Kikuchi, H.; Tsukitani, Y.; Manda, T.; Fujii, T.; Nakanishi, H.; Kobayashi, M.; Kitagawa, I. Chem. Pharm. Bull. 1982, 30, 3544.

14. Helrich, K. Association of Official Analytical Chemists, 'Official Methods of Analysis', $15^{\text {th }}$ Ed. Arlington, VA 1990, 513.

15. Tubaro, A.; Dri, P.; Delbello, G.; Zilli, C.; Della Loggia, R. Agents Actions 1985, 17, 347. 